\title{
METHOD FOR DETERMINATION OF AMINO ACID CONTENT IN PROTEIN PRODUCTS FOR MEDICAL USE
}

\author{
Gabriela MACOVESCU*, Ciprian CHELARU, Dana GURĂU
}

INCDTP - Division: Leather and Footwear Research Institute, 93 Ion Minulescu St., Bucharest, Romania, email: icpi@icpi.ro

Accepted: 28.11.2017

https://doi.org/10.24264/Ifj.17.4.8

METHOD FOR DETERMINATION OF AMINO ACID CONTENT IN PROTEIN PRODUCTS FOR MEDICAL USE

ABSTRACT. The paper presents a method for determination of amino acid content in collagen biomaterials for medical use produced in the Collagen Department of INCDTP - Division ICPI and its validation. The method has three stages: the first consists in hydrolysing the collagen biomaterial sample down to amino acids; the second step refers to derivatization of amino acids with N, O-bis (trimethylsilyl) trifluoroacetamide (BSTFA) which is a silylation reagent; derivatized amino acids are detected using a mass spectrometer after gas chromatography. The method was validated to establish performance parameters and to check compliance with the intended purpose.

KEY WORDS: collagen, amino acids, biomaterials

METODĂ PENTRU DETERMINAREA CONTINUTULUI DE AMINOACIZI DIN PRODUSELE PROTEICE PENTRU UZ MEDICAL

REZUMAT. Se prezintă o metodă de determinare a conţinutului de aminoacizi din biomaterialele colagenice pentru uz medical produse în Departamentul Colagen al INCDTP - Sucursala ICPI şi validarea ei. Metoda are trei etape: prima constă în hidroliza probei de biomaterial colagenic până la stadiul de aminoacizi; a doua etapă se referă la derivatizarea aminoacizilor cu N, O-bis (trimetilsilil) trifluoracetamidă (BSTFA) care este un reactiv de sililare; aminoacizii derivatizaţi sunt detectaţi pe un spectrometru de masă după gaz cromatografie. Metoda a fost validată pentru a se stabili parametrii de performanţă şi pentru verificarea conformării cu scopul propus.

CUVINTE CHEIE: colagen, aminoacizi, biomateriale

PROCÉDÉ DE DÉTERMINATION DE LA TENEUR EN ACIDES AMINÉS DANS DES PRODUITS PROTÉIQUES À USAGE MÉDICAL

RÉSUMÉ. On présente une méthode de détermination de la teneur en acides aminés de biomatériaux de collagène à usage médical fabriqués dans le Département Collagène de INCDTP-ICPI et sa validation. La méthode comporte trois étapes : la première consiste en l'hydrolyse de l'échantillon de biomatériau de collagène au stade des acides aminés; la deuxième étape se rapporte à la dérivatisation d'acides aminés avec du N, O-bis (triméthylsilyl) trifluoroacétamide (BSTFA) qui est un réactif de silylation; les acides aminés dérivés sont détectés sur un spectromètre de masse après chromatographie en phase gazeuse. La méthode a été validée pour établir les paramètres de performance et vérifier la conformité avec l'objectif prévu.

MOTS CLÉS : collagène, acides aminés, biomatériaux

* Correspondence to: Gabriela MACOVESCU, INCDTP - Division: Leather and Footwear Research Institute, 93 lon Minulescu St., Bucharest, Romania, email: icpi@icpi.ro 


\section{INTRODUCTION}

Collagen is the main structural protein in soft, lax, semirigid and rigid conjunctive tissues (skin, bones, tendons, basal membranes, etc.), that primarily provides structural integrity to tissues, but also plays an important role in determining the cell phenotype and in cell adhesion.

Due to its excellent biocompatibility and biodegradability, well-defined structure, biological characteristics and to the way it interacts with the body, collagen is always one of the most widely used biomaterials. Extracted as aqueous solution or gel, type I fibrillar collagen may be moulded into various forms: medical devices, artificial implants, drug delivery systems and scaffolds for tissue regeneration, with an important role in today's medicine [1-5].

As a natural protein, collagen cannot heal by itself the infected tissue because bacteria may use it as a substrate. In severe wound infections, systemic drug delivery may lead to an insufficient drug concentration in the infected area or to side effects associated with the drug and/or to systemic toxicity. This deficiency was successfully solved by local drug delivery, developing drug delivery systems with collagen as a substrate and an antibiotic/antiseptic as a drug for infection control $[2,4,6,7]$.

The primary structure of collagen is determined by the sequence of the 20 amino acids that "build" first $\alpha$-helix polypeptide chains (secondary structure) by peptide bonds, and then the tertiary and quaternary macromolecular superstructure is formed by means of $\alpha$-helixes.

Amino acids are particularly important for the human body. They are basic structural elements of proteins, compounds with a remarkable biological importance. Amino acids may be obtained from proteins by acid, basic or enzymatic hydrolysis of peptide bonds.

The following amino acids are included in the collagen composition: glycine (1/3), alanine, proline, hydroxyproline $(1 / 3)$ and other amino acids (1/3). Amino acids are found in a triple helix conformation: two polypeptide chains are identical, and the third slightly differs in the amino acid composition [8-10].

In the polypeptide chain the amino acids form peptide bonds by coupling the carboxyl group to an amino group; once bound in the protein chain, the amino acid "turns" into a "residual" amino acid, and the carbon, nitrogen, hydrogen and oxygen atoms involved in the bonds form the "skeleton" of the protein. As a result, it is necessary to know the amino acid composition of the products for medical purposes when establishing links between the affected tissues and the products used in the treatments.

As a result, a study was conducted on methods of analysis of amino acid content in protein products, biological fluids, foodstuffs and fodders, in order to develop a qualitative and quantitative method for the identification of amino acids in collagen-based medical materials, for better knowledge of product structure, reproducibility of batches and for improving their quality.

The proposed method was validated in order to establish performance parameters and to check compliance to the intended purpose by determining: detection limit, quantification limit, selectiveness, sensitivity, robustness, accuracy and reliability of the method.

The method of amino acid analysis in collagen-based materials for medical use was verified in order to ensure reproducibility and is supported by determinations carried out on samples from the Collagen Department of ICPI.

\section{MATERIALS AND METHOD}

\section{Method Principle}

Determination of amino acids from collagen materials for medical use is carried out based on the following three basic stages:

a) Hydrolysis of collagen materials for medical use, with $6 \mathrm{M}$ hydrochloric acid, for 24 hours at $1000 \mathrm{C}$;

b) The resulting amino acids are evaporated to dryness to remove moisture and resuspended with acetonitrile to derivatize with $\mathrm{N}, \mathrm{O}$-bis (trimethylsilyl) trifluoracetamide (BSTFA) which is a silylation reagent;

c) Derivatized amino acids are detected using a mass spectrometer after gas chromatography.

\section{Reagents}

Only reagents of known analytical grade and distilled water or demineralized water or 
equivalent purity water are used.

- L-alanine (Ala), L-glycine (Gly), L-proline (Pro), L-aspartic acid (Asp), L-glutamic acid (Glu), all these amino acid standards were purchased from Sigma-Aldrich;

- Derivatizing agent N, O-bis (trimethylsilyl) trifluoroacetamide (BSTFA) purchased from Merck;

- Hydrochloric acid ( $\mathrm{HCl}) 6 \mathrm{M}$ was used as hydrolysis agent $(\mathrm{HCl}) 0,1 \mathrm{M}$;

- Acetonitrile, purchased from Merck.

\section{Equipment}

- NANOCOLOR VARIO C2 thermoblock for hydrolysis of collagen materials;

- TurboVap II equipment for concentration of samples using nitrogen gas;

- FOCUS GC Gas chromatograph coupled with DSQ II MS mass spectrometer, AutoSampler Triplus, flame ionization detector, Split/Split less injector, XCalibur Thermo Scientific software, equipped with a non-polar capillary column;

- capillary column: TR 5MS: 5\% phenyl 95\% dimethylpolysiloxane, length: $60 \mathrm{~m}$, inner diameter: 0,32 $\mathrm{mm}$, film thickness: $0,25 \mu \mathrm{m}$.

\section{WORK METHOD}

\section{Sample Preparation}

- About 5 mg solid samples were weighed with an accuracy of $0.01 \mathrm{mg}$ and approximately $100 \mathrm{mg}$ liquid samples were weighed with an accuracy of 0.01 $\mathrm{mg}$;

- $1 \mathrm{ml}$ of $6 \mathrm{M}$ hydrochloric acid solution as hydrolysis agent was added, the tube was covered and placed in the aluminium thermoblock at $100^{\circ} \mathrm{C} \pm 20^{\circ} \mathrm{C}$ for 24 hours for hydrolysis;

- Using a pipette, a volume of $100 \mu \mathrm{l}$ of hydrolysed is introduced in a vial placed in TurboVap to remove moisture with nitrogen gas;

- The dried amino acid residues were dissolved in a volume of $100 \mu$ of acetonitrile;

- They are derivatized with a volume of $100 \mu \mathrm{l}$ of $\mathrm{N}$, O-bis (trimethylsilyl) trifluoroacetamide;
- The sealed vial is subjected to ultrasound for 1 minute;

- The vial is placed in the thermoblock at $100^{\circ} \mathrm{C}+2^{\circ} \mathrm{C}$ for $30 \mathrm{~min}$. to complete the derivatization reaction;

- The vial is placed in the gas chromatograph sample stand;

- 10 injections of $1 \mu$ per sample are performed.

\section{Standard Stock Solutions}

Standard amino acid stock solutions were prepared by dissolving each amino acid in $0.1 \mathrm{M} \mathrm{HCl}$ down to a concentration of $5 \mu \mathrm{mol} /$ $\mathrm{ml}$. The solutions were stored at $4^{\circ} \mathrm{C}$ until analysis. The calibration standards at 4 different concentrations $(0.625-5 \mu \mathrm{mol} / \mathrm{ml}$ were prepared using standard amino acid stock solutions.

Standard amino acid samples were processed by dissolving about $0.1 \mathrm{mg}$ of each amino acid in $1 \mathrm{ml}$ of $0.1 \mathrm{M}$ hydrochloric acid. A $100 \mu \mathrm{l}$ volume was dried under a constant nitrogen stream.

The remaining amino acid was dissolved in a volume of $100 \mu \mathrm{l}$ acetonitrile and derivatised with a volume of $100 \mu$ l of N, O-bis (trimethylsilyl) trifluoroacetamide (BSTFA) and analyzed by GC/ MS.

\section{RESULTS AND DISCUSSIONS}

Since collagen materials for medical purposes in the form of sponges, gels, atomized or liquid hydrolysates are stabilized for good preservation over time, acid hydrolysis has been chosen until the matrix is destroyed and individual amino acids are released.

Hydrochloric acid has been chosen because it has been found to be the most widely used, with the advantage that it is not an oxidizing acid and can be removed quickly from the system.

Several variants of hydrolysis have been attempted, ranging from 2 hours to 24 hours, and it has been observed that a good separation of the amino acids from the samples requires a longer time, therefore a 24-hour hydrolysis at $100^{\circ} \mathrm{C}$ was opted for.

$\mathrm{N}, \mathrm{O}$-bis (trimethylsilyl) trifluoroacetamide (BSTFA) (Figure 1 ) is a common silylation reagent that replaces acidic protons of amino acids (e.g. $\mathrm{SH}, \mathrm{OH}, \mathrm{NH}$ and $\mathrm{COOH}$ ) with nonpolar trimethylsilane groups (TMS). 
<smiles>C[Si](C)(C)/N=C(\O[Si](C)(C)C)C(F)(F)F</smiles>

Figure 1. Chemical formula of $\mathrm{N}, \mathrm{O}-\mathrm{b}$ is (trimethylsilyl) trifluoroacetamide (BSTFA)

According to some studies, by replacing acidic protons with nonpolar TMS groups, polarity of an amino acid is reduced and its volatility is increased [11-17] which is an advantage in gas chromatographic analysis.

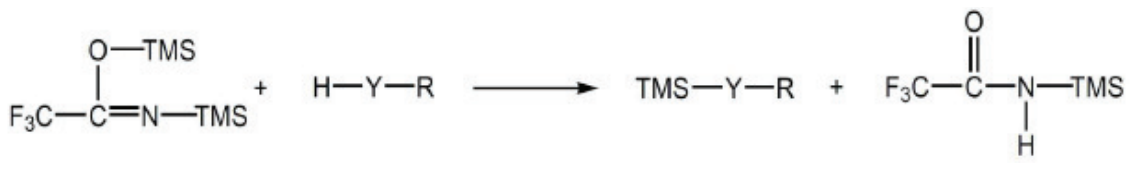
analysis.
Equation (1) represents derivatization (silylation reaction) of amino acids in which TMS=Si(CH3)3, Y=O, S, NH, COO and R= alkyl or aryl radical.

The advantage of derivatization with TMS is that it requires a single step, while other derivatization methods usually have two or more reaction steps.

The major drawbacks of TMS derivatives are the sensitivity to moisture and the derivatization of Gly and Glu, which are affected by the polarity of the solvent [18-20]. For example, both the di-trimethylsilyl derivative and the trimethylsilyl derivatives of glycine are obtained after derivatization using acetonitrile or acetone as solvents [18].

Amino acids derivatized with TMS are typically analyzed using gas chromatography coupled with mass spectrometry (GC / MS) and identified according to a combination of retention times and mass spectra [21,22].

GC / MS is a powerful tool for separating and identifying components in complex mixtures and plays a central role in amino acid analysis, presenting the advantages of improved resolution, sensitivity and quantification of smaller amounts in the sample as well as rapid

The literature reports contradictory results with regard to optimal amino acid derivatization conditions using BSTFA. These results may be related to several limitations that were observed in those studies, such as the limited number of iterations for each of the derivatization conditions [22-24], using either peak height or peak area without evaluating the calibration linearity, sensitivity, or the limit of detection (LOD), using either SCAN mode or SIM mode, or using relatively long $G C$ temperature programs (e.g. $54 \mathrm{~min}$ [25], $62 \mathrm{~min}$ [26], and $90 \mathrm{~min}$ [27]).

The derivatized amino acids were analyzed with a FOCUS GC gas chromatograph coupled with a DSQ II MS mass spectrometer,

TriPlus AutoSampler, flame ionization detector, Split/Split less injector, XCalibur Thermo Scientific software equipped with a nonpolar capillary column: TR 5MS: 5\% phenyl - 95\% dimethylpolysiloxane, length: $60 \mathrm{~m}$, inner diameter: $0.32 \mathrm{~mm}$, film thickness: $0.25 \mu \mathrm{m}$; ultra-high purity helium was used as carrier gas at a constant flow rate of $20 \mathrm{ml} / \mathrm{min}$. The column transfer flux was $1.0 \mathrm{ml} / \mathrm{min}$.

The column temperature was programmed to increase from $700^{\circ} \mathrm{C}$ to $1700^{\circ} \mathrm{C}$ at a rate of $100^{\circ} \mathrm{C} / \mathrm{min}$, and then was raised to $280^{\circ} \mathrm{C}$ at a rate of $30^{\circ} \mathrm{C} / \mathrm{min}$, the temperature at which the elution took place for $8 \mathrm{~min}$. Total running time was $21 \mathrm{mins} 66 \mathrm{sec}$.

The sample was injected at $280^{\circ} \mathrm{C}$ in split injection mode (ratio 1:20) using an injection volume of $1 \mu \mathrm{l}$.

For each sample, triple injections were performed and the results were averages of the three determinations. Acetonitrile was also used as a control solvent before each injection. Three solvent ampoules, namely acetonitrile, methanol, acetone, were used successively as cleaning solvents for the autosampler injection syringe. 
Amino acids were detected with a mass spectrometer in automatic scanning mode (SCAN), and the individual identification was performed using the specific retention times of the reference materials and the spectra library of the device. In Selected Ion Monitoring Mode (SIM), identification was made based on specific fragments of maximum intensity.

The mass spectrometer operated in full scan mode (SCAN) at $\mathrm{m} / \mathrm{z}$ of 50 to $\mathrm{m} / \mathrm{z}$ of 650 , with a scan time of $0.3 \mathrm{~s}$ and in the selected ion monitoring mode (SIM) with a scanning time of $0.2 \mathrm{~s}$.

\section{VALIDATION OF THE METHOD}

The validation method and the analysis procedure of the amino acid content were performed according to validation guides for EURACHEM analytical methods.

The concentration range is the interval between the lower and upper concentration of the analyte in the assay for which it has been demonstrated that the procedure has an appropriate level of precision, accuracy and linearity.

Linearity is the ability of an analytical method to yield results proportional to the concentration of the analyte in the sample.

As a result, these parameters have been studied for the four amino acid standards which have an important share in collagen hydrolysates, namely:

- Glycine;

- Proline;

- Glutamic acid;

- Aspartic acid.

To evaluate the linearity and sensitivity of the signal in relation to the concentration, eight linear calibrations were generated for each amino acid.

The calibration curves of each amino acid were plotted in the $0.625-5 \mu \mathrm{mol} / \mathrm{ml}$ range, and the linearity range for which the correlation coefficient that characterizes the regression line R2 was obtained, was examined visually.

The mass spectrometer operated in automatic scanning mode (SCAN) and selected ion monitoring mode (SIM). The mass spectrometer operated in full scan mode (SCAN) at $\mathrm{m} / \mathrm{z}$ of 50 to $\mathrm{m} / \mathrm{z}$ of 500 , with a scan time of $0.3 \mathrm{~s}$ and in Selected Ion Monitoring Mode (SIM) with a scan time of $0.2 \mathrm{~s}$.

The performance parameters of the reference amino acid method, concentrations, limit of detection (LOD), limit of quantification (LOQ) and calibration curves were statistically calculated using Excel 2010 and are shown in Table 1. All statistical tests were performed at a confidence level of $95 \%$ and $k=2$.

Table 1: Performance parameters of the amino acid determination method

\begin{tabular}{lllll}
\hline Amino acid & $\begin{array}{c}\text { Correlation } \\
\text { coefficient } \mathrm{R}^{2}\end{array}$ & $\begin{array}{c}\text { Limit of } \\
\text { detection } \\
\text { LOD } \\
\mu \mathrm{mol} / \mathrm{ml}\end{array}$ & $\begin{array}{c}\text { Limit of } \\
\text { quantification } \\
\text { LOQ }\end{array}$ & Retention time \\
\hline Glycine SCAN & 0,9999 & 0.004365 & 0.014549 & 8,98 \\
Glycine SIM & 0,9996 & 0.01817 & 0.060565 & 8,98 \\
Proline SCAN & 0,9998 & 0.010724 & 0.035745 & 11,40 \\
Proline SIM & 0,9999 & 0.002622 & 0.00874 & 11,40 \\
Glutamic acid SCAN & 0,9995 & 0.001592 & 0.005308 & 13,59 \\
Glutamic acid SIM & 0,9999 & 0.003978 & 0.013261 & 13,60 \\
Aspartic acid SCAN & 0,9999 & 0.005337 & 0.01779 & 13,37 \\
Aspartic acid SIM & 0,9998 & 0.096521 & 0.321737 & 13,33 \\
\hline
\end{tabular}




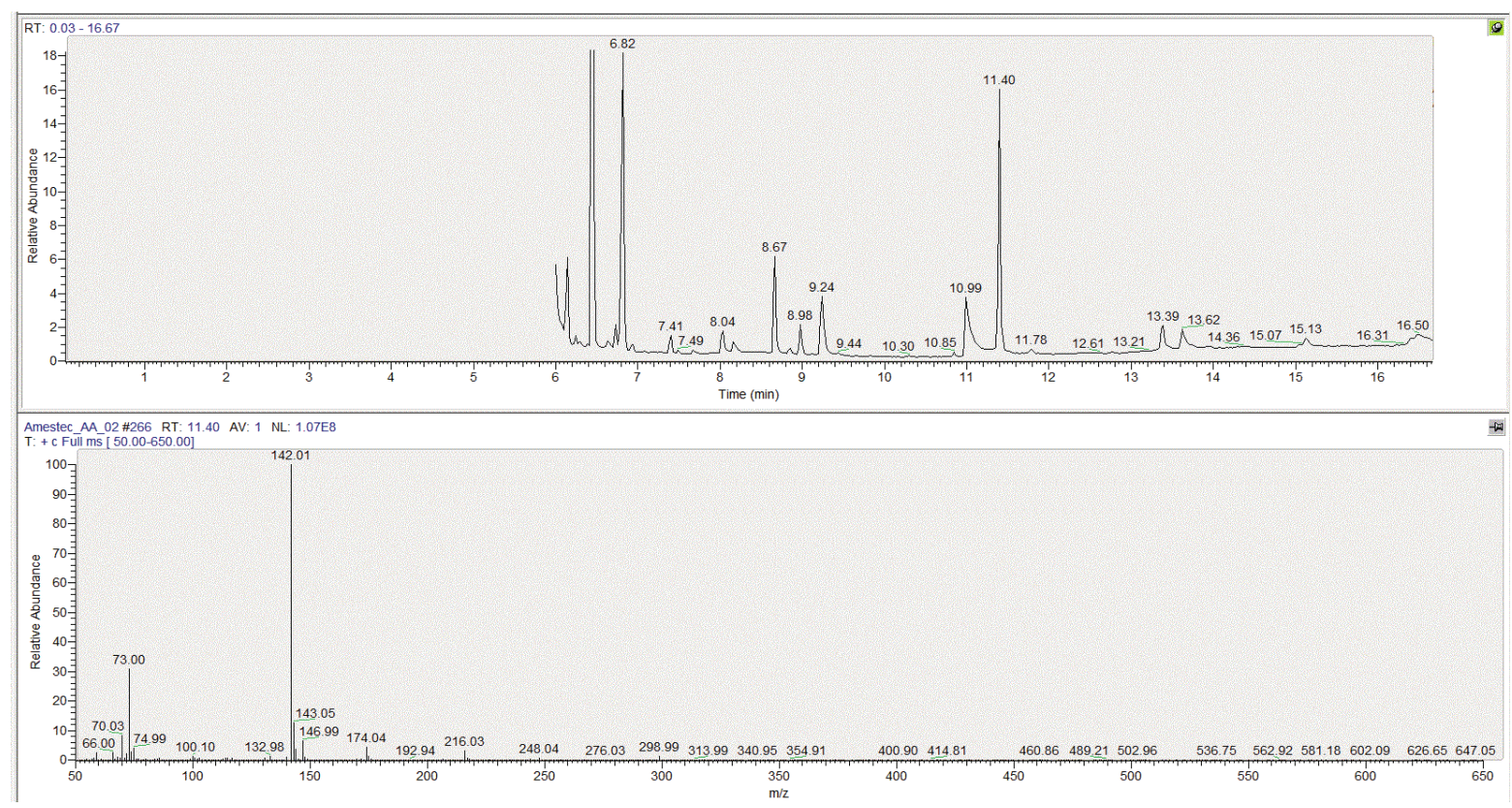

Figure 2. GC-MS chromatogram of standard amino acids in the mixture

\section{ANALYSES OF BIOMATERIALS FOR MEDICAL USE}

Seven samples of collagen materials for medical use were studied and physically and chemically characterized, the results are presented in the table below:

Table 2: Characterization of collagen products for medical use

\begin{tabular}{lcccc}
\hline \multicolumn{1}{c}{ Characteristics } & & & & \\
& Dry substance, \% & Ash*, \% & Total nitrogen*, \% & Appearance \\
\hline Pancol L1 & & & & \\
Pancol L2 & 85,79 & 1,64 & 15,78 & White spongy foil \\
Gevicol G1 & 87,43 & 1,96 & 15,19 & White spongy foil \\
Gevicol G2 & 87,57 & 2,72 & 16,45 & Violet spongy foil \\
Gel Zetta Skin 5 & 86,52 & 1,46 & 14,80 & Violet spongy foil \\
Collagen hydrolysate HO 8 (Liquid) & 2,10 & 0,95 & 17,62 & Transparent gel \\
Collagen hydrolysate HO8 (Atomized) & 28,76 & 0,56 & 17,62 & Yellow liquid \\
\hline
\end{tabular}

*values are recalculated free of volatile matter

The samples were hydrolyzed with $6 \mathrm{M}$ hydrochloric acid at $100^{\circ} \mathrm{C} \pm 2^{\circ} \mathrm{C}$ for 24 hours, and the aliquot of the hydrolyzed sample was dried with nitrogen gas.

The derivatization was performed with $\mathrm{N}$, O-bis (trimethylsilyl) trifluoroacetamide (BSTFA), and subsequently the derivatized amino acids were analyzed with a FOCUS GC gas chromatograph coupled with a DSQ II MS mass spectrometer, TriPlus AutoSampler, flame ionization detector, Split/Split less injector, XCalibur Thermo Scientific software, equipped with a non-polar capillary column.

Samples of collagen materials for medical use, hydrolysed, derivatized and analyzed by the mass spectrometric gas chromatographic method are shown in Figures 3-14, and the amino acid composition in Tables 3-9. 


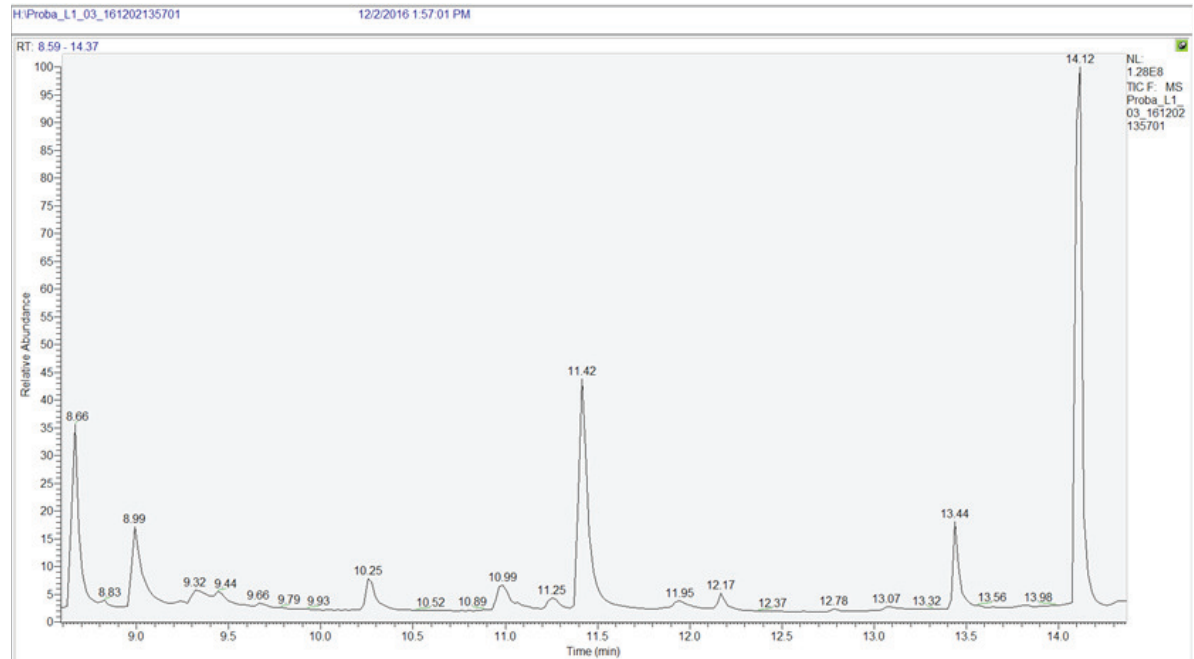

Figure 3. GC-MS profile of amino acids in Pancol L1

The amino acid composition of the Pancol shown in Table 3. L1 sample and the retention times obtained are

Table 3: Amino acid composition of Pancol L1 sample

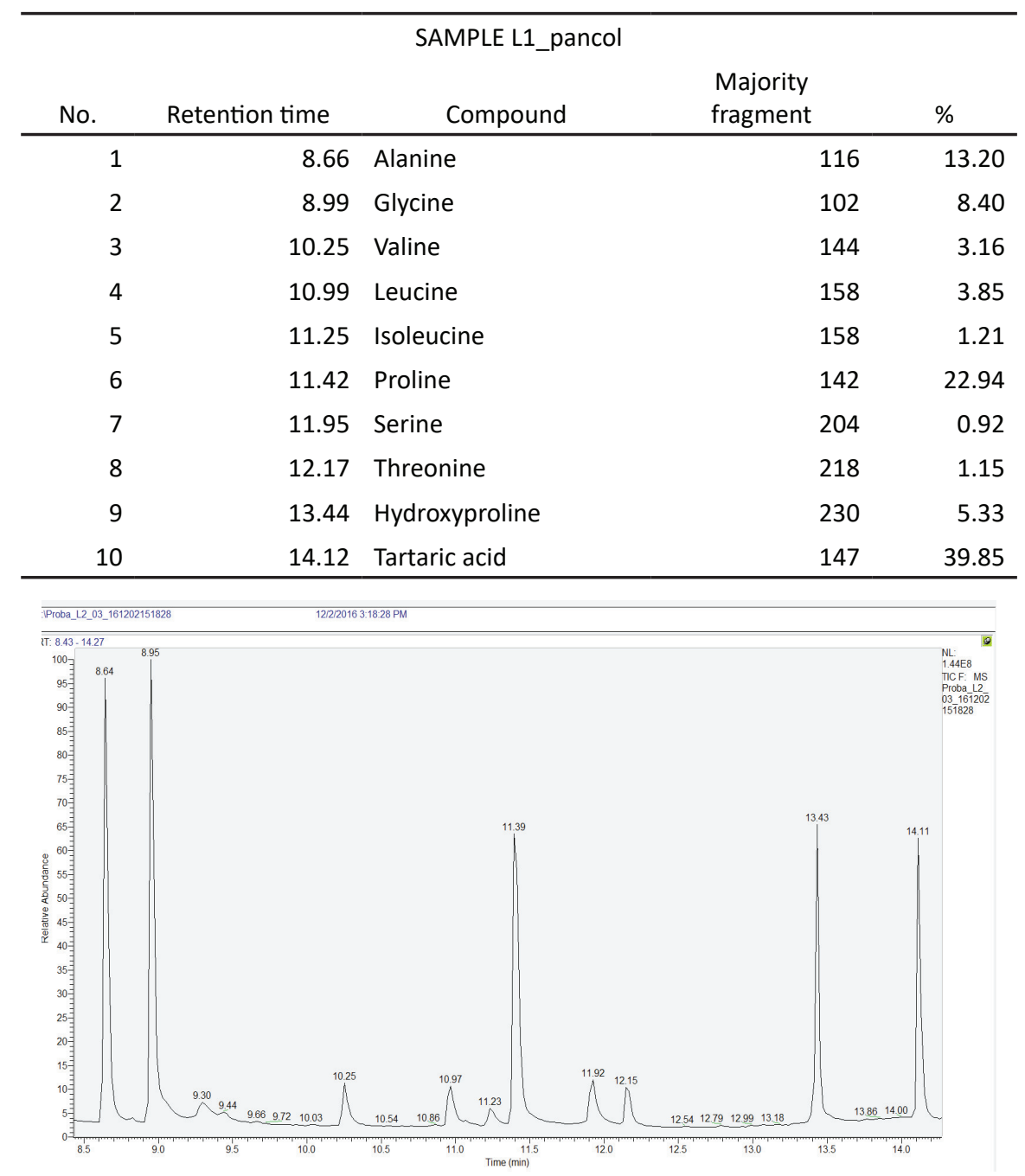

Figure 4. GC-MS profile of amino acids in Pancol L2 
Table 4: Amino acid composition of Pancol L2 sample

\begin{tabular}{|c|c|c|c|c|}
\hline \multicolumn{5}{|c|}{ SAMPLE L2_pancol } \\
\hline No. & Retention time & Compound & $\begin{array}{l}\text { Majority } \\
\text { fragment }\end{array}$ & $\%$ \\
\hline 1 & 8.64 & Alanine & 116 & 20.79 \\
\hline 2 & 8.95 & Glycine & 102 & 24.56 \\
\hline 3 & 10.25 & Valine & 144 & 2.36 \\
\hline 4 & 10.97 & Leucine & 158 & 3.14 \\
\hline 5 & 11.23 & Isoleucine & 158 & 1.26 \\
\hline 6 & 11.39 & Proline & 142 & 18.72 \\
\hline 7 & 11.92 & Serine & 204 & 2.89 \\
\hline 8 & 12.15 & Threonine & 218 & 2.19 \\
\hline 9 & 13.43 & Hydroxyproline & 230 & 11.47 \\
\hline 10 & 14.11 & Tartaric acid & 147 & 12.62 \\
\hline
\end{tabular}

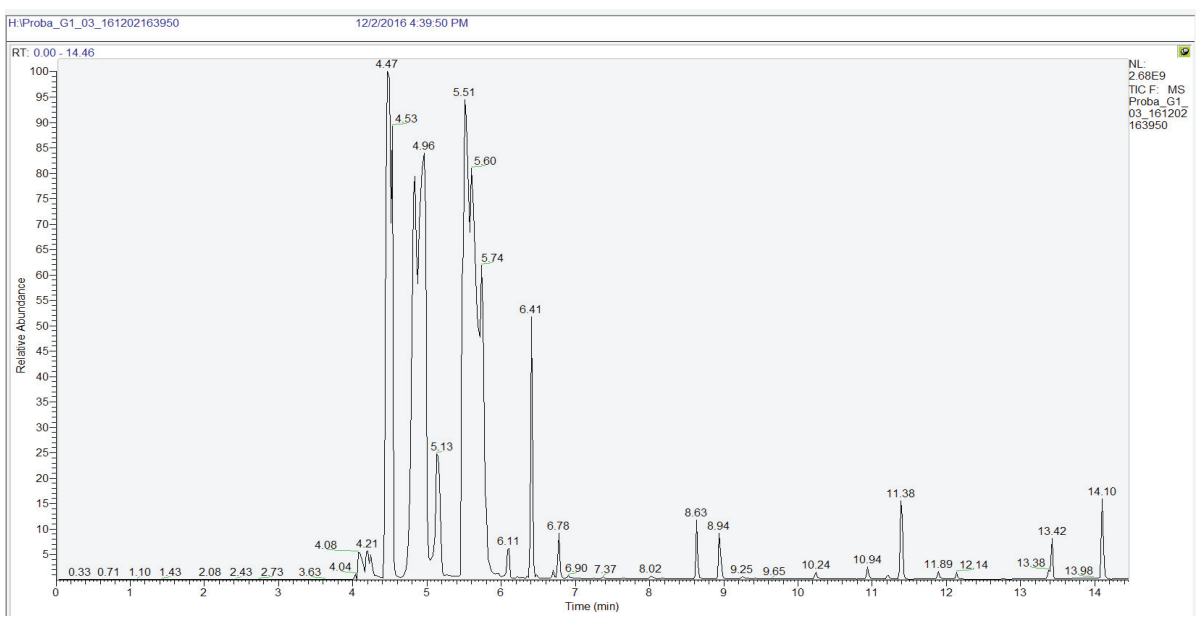

Figure 5. GC-MS chromatogram of Gevicol G1 sample

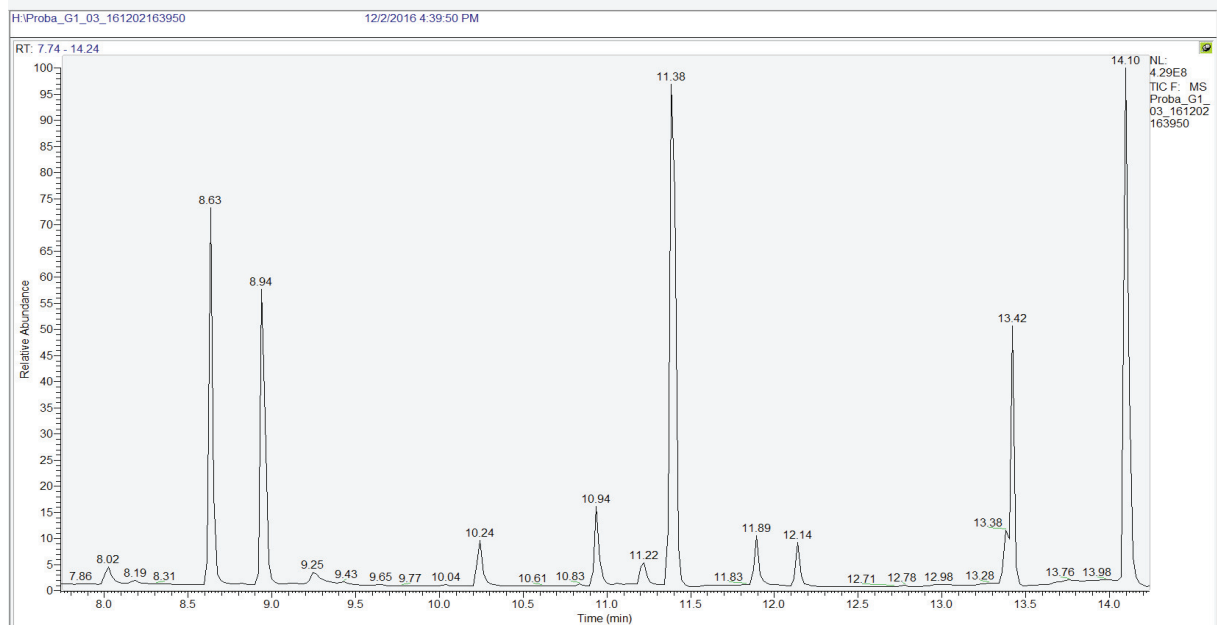

Figure 6. GC-MS profile of amino acids in Gevicol G1 
Table 5: Amino acid composition of Gevicol G1 sample

\begin{tabular}{|c|c|c|c|c|}
\hline \multicolumn{4}{|c|}{ SAMPLE G1_gevicol } & \multirow{2}{*}{$\begin{array}{c}5.83 \mathrm{mg} \\
\%\end{array}$} \\
\hline No. & Retention time & Compound & Majority fragment & \\
\hline 1 & 8.02 & Lactic acid & 147 & 1.11 \\
\hline 2 & 8.63 & Alanine & 116 & 13.70 \\
\hline 3 & 8.94 & Glycine & 102 & 13.69 \\
\hline 4 & 10.24 & Valine & 144 & 2.35 \\
\hline 5 & 10.94 & Leucine & 158 & 3.54 \\
\hline 6 & 11.22 & Isoleucine & 158 & 1.27 \\
\hline 7 & 11.38 & Proline & 142 & 27.33 \\
\hline 8 & 11.89 & Serine & 204 & 2.19 \\
\hline 9 & 12.14 & Threonine & 218 & 1.74 \\
\hline 10 & 13.38 & Acid Aspartic & 232 & 2.37 \\
\hline 11 & 13.42 & Hydroxyproline & 230 & 8.09 \\
\hline 12 & 14.1 & Tartaric acid & 147 & 22.61 \\
\hline
\end{tabular}

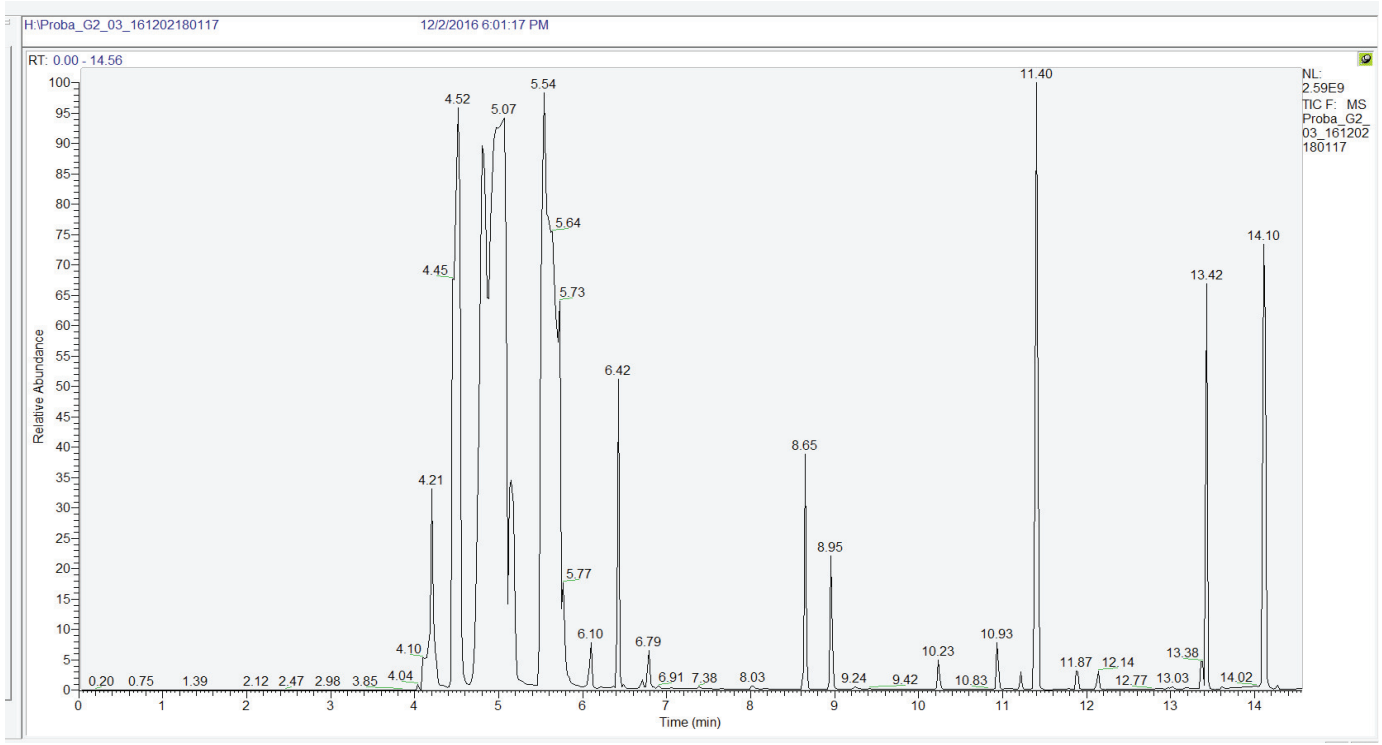

Figure 7. GC-MS chromatogram of Gevicol G 2 sample 


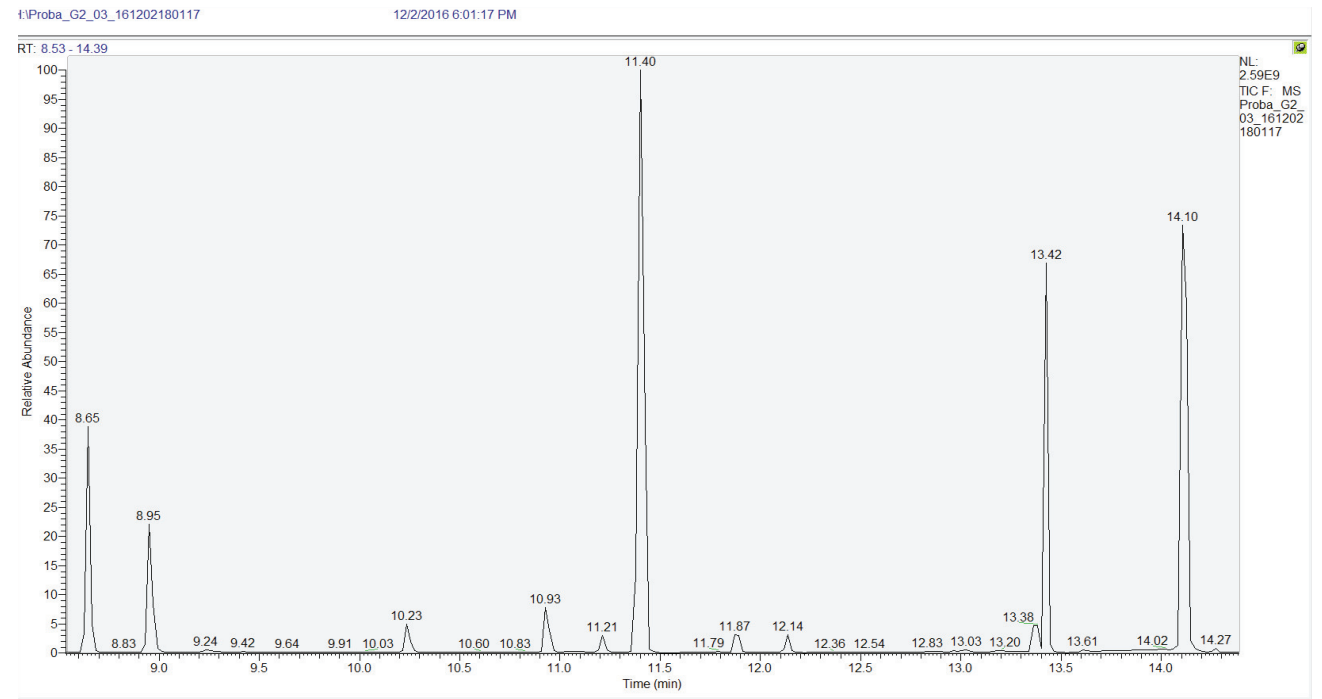

Figure 8. GC-MS profile of amino acids in Gevicol G2

Table 6: Amino acid composition of Gevicol G2 sample

\begin{tabular}{|c|c|c|c|c|}
\hline \multirow[b]{2}{*}{ No. } & \multicolumn{2}{|c|}{ SAMPLE G2_gevicol } & \multirow[b]{2}{*}{ Majority fragment } & \multirow{2}{*}{$\begin{array}{c}5.13 \mathrm{mg} \\
\%\end{array}$} \\
\hline & Retention time & Compound & & \\
\hline 1 & 8.65 & Alanine & 116 & 9.41 \\
\hline 2 & 8.95 & Glycine & 102 & 6.50 \\
\hline 3 & 10.23 & Valine & 144 & 1.39 \\
\hline 4 & 10.93 & Leucine & 158 & 2.23 \\
\hline 5 & 11.21 & Isoleucine & 158 & 0.72 \\
\hline 6 & 11.4 & Proline & 142 & 34.69 \\
\hline 7 & 11.87 & Serine & 204 & 1.16 \\
\hline 8 & 12.14 & Threonine & 218 & 0.76 \\
\hline 9 & 13.36 & Aspartic acid & 232 & 1.75 \\
\hline 10 & 13.42 & Hydroxyproline & 230 & 14.20 \\
\hline 11 & 14.1 & Tartaric acid & 147 & 27.18 \\
\hline
\end{tabular}

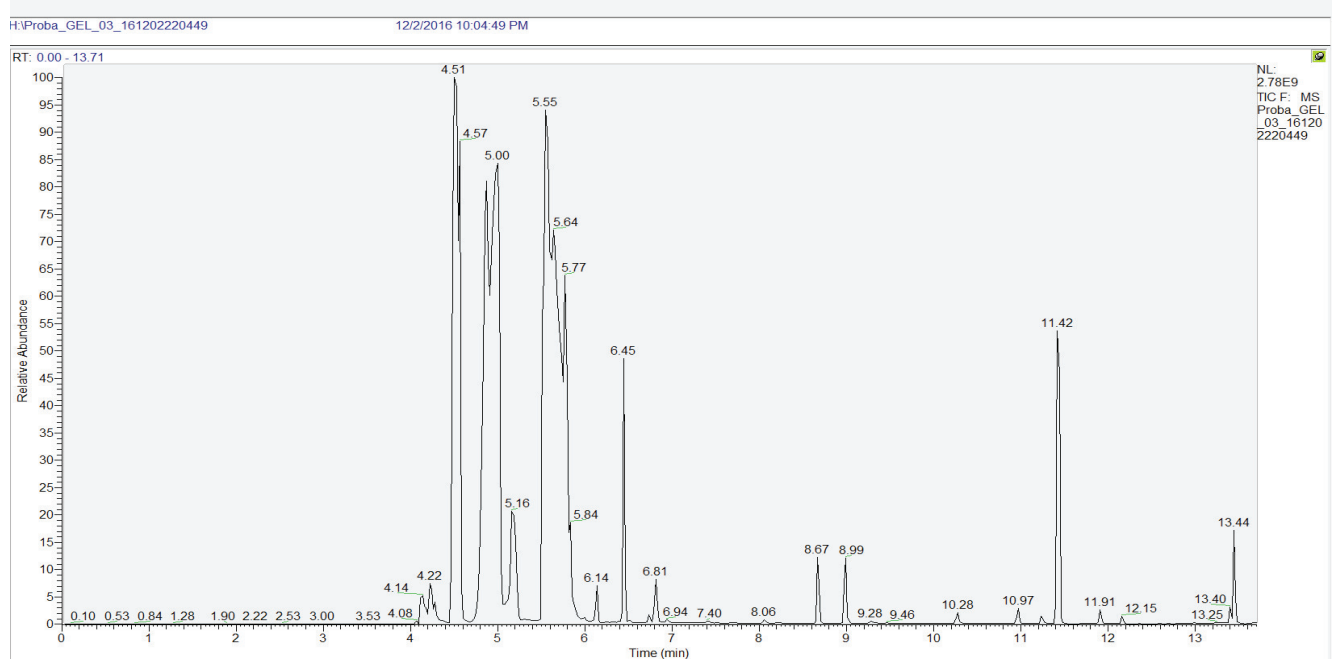

Figure 9. GC-MS chromatogram of Gel zeta sample 


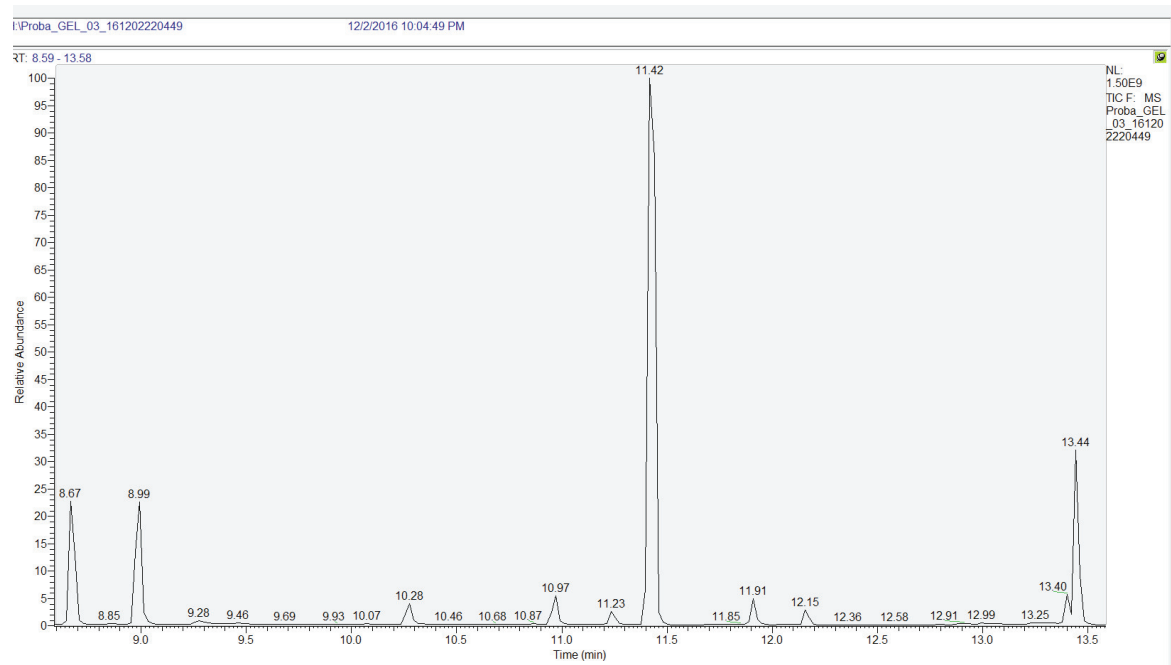

Figure 10. GC-MS profile of amino acids in Gel zeta

Table 7: Amino acid composition of Gel zeta sample

\begin{tabular}{|c|c|c|c|c|}
\hline \multirow[b]{2}{*}{ No. } & \multicolumn{3}{|c|}{ SAMPLE GEL_zeta } & \multirow[b]{2}{*}{$\%$} \\
\hline & Retention time & Compound & $\begin{array}{l}\text { Majority } \\
\text { fragment }\end{array}$ & \\
\hline 1 & 8.67 & Alanine & 116 & 10.13 \\
\hline 2 & 8.99 & Glycine & 102 & 10.65 \\
\hline 3 & 10.28 & Valine & 144 & 1.91 \\
\hline 4 & 10.97 & Leucine & 158 & 2.22 \\
\hline 5 & 11.23 & Isoleucine & 158 & 1.01 \\
\hline 6 & 11.42 & Proline & 142 & 57.25 \\
\hline 7 & 11.91 & Serine & 204 & 1.67 \\
\hline 8 & 12.15 & Threonine & 218 & 1.07 \\
\hline 9 & 13.4 & Acid Aspartic & 232 & 1.67 \\
\hline 10 & 13.44 & Hydroxyproline & 230 & 11.19 \\
\hline 11 & 14.12 & Tartaric acid & 147 & 0.43 \\
\hline 12 & 14.32 & Phenylalanine & 218 & 0.32 \\
\hline 13 & 15.77 & Lysine & 174 & 0.49 \\
\hline
\end{tabular}

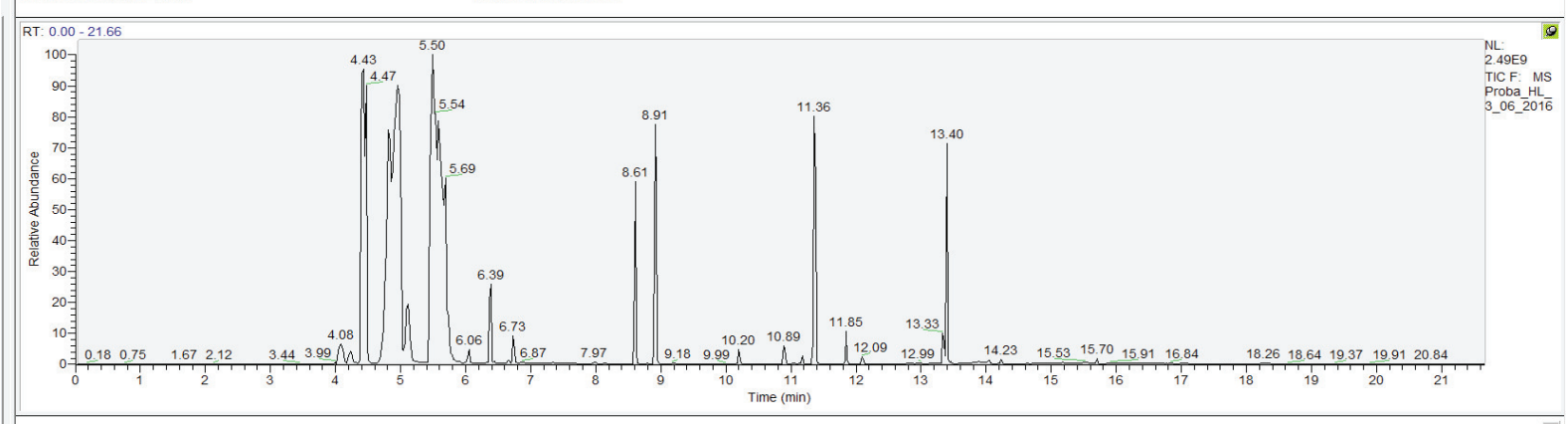

Figure 11. GC-MS chromatogram of liquid HO8 sample 


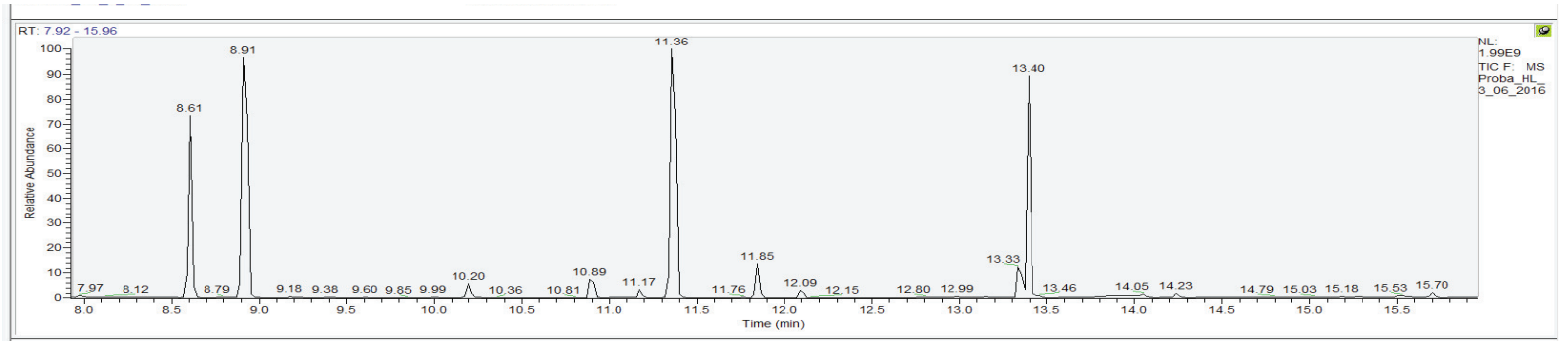

Figure 12. GC-MS profile of amino acids in liquid HO8

Table 8: Amino acid composition of liquid HO8 sample

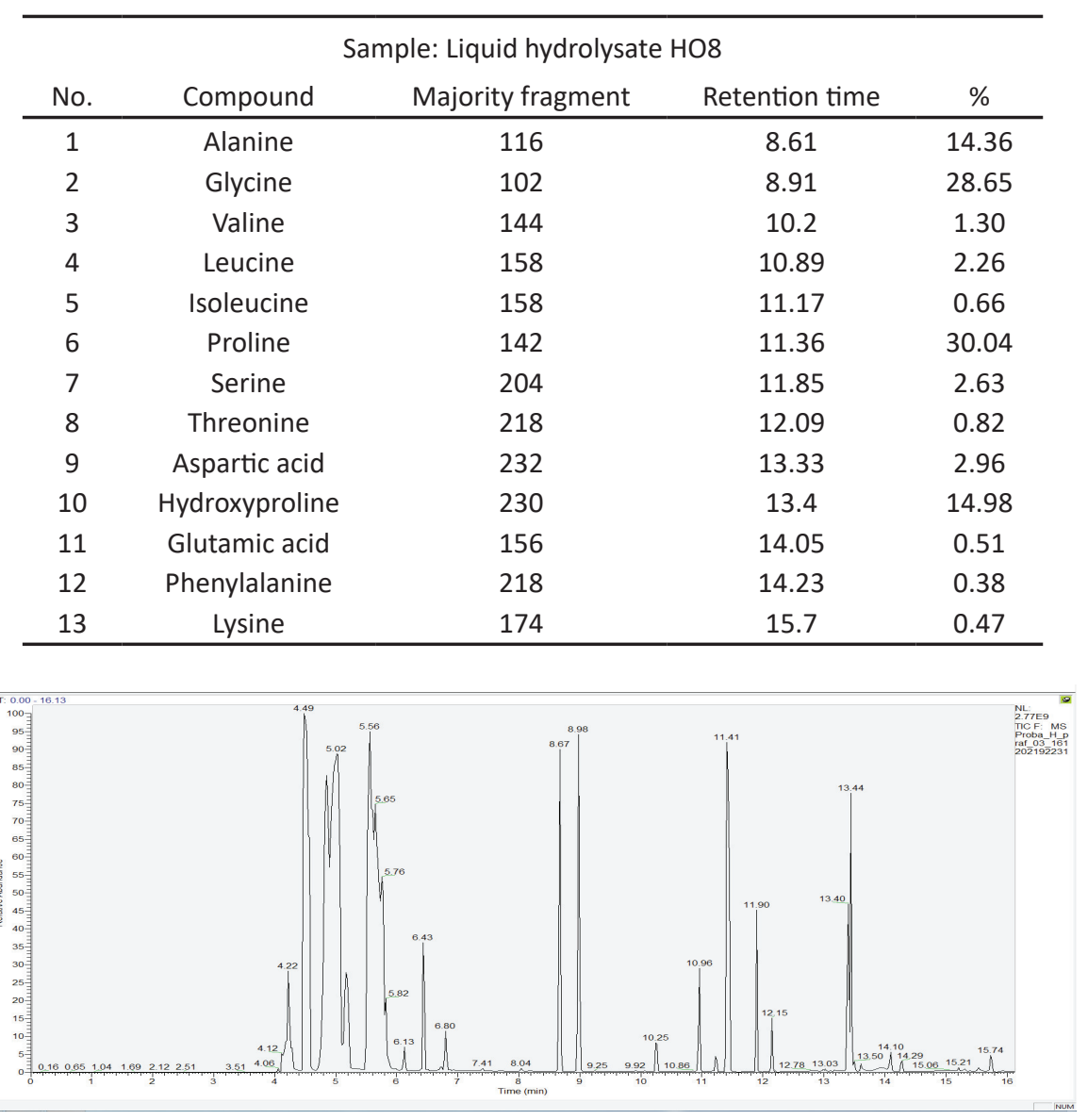

Figure 13. GC-MS chromatogram of atomized HO8 sample

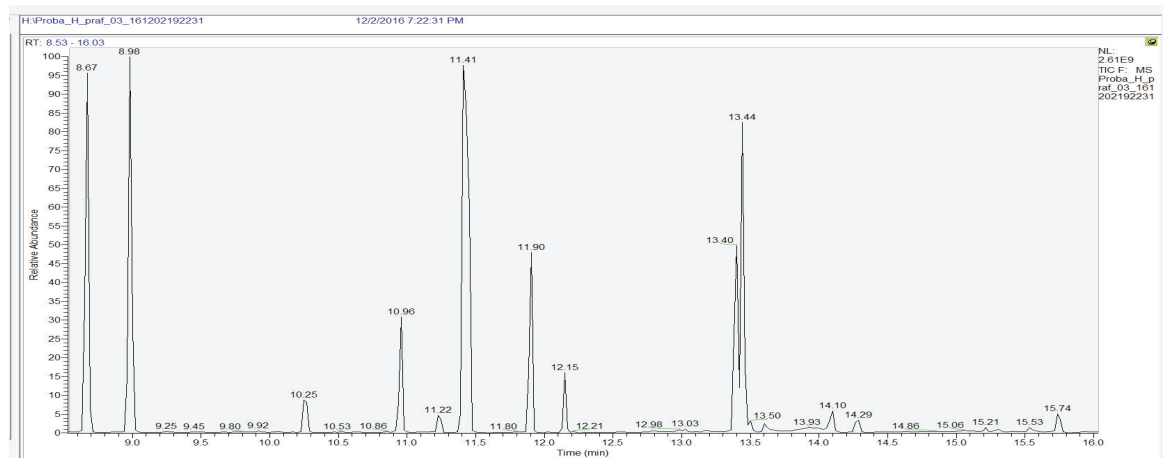

Figure 14. GC-MS profile of amino acids in atomized $\mathrm{HO} 8$ 
Table 9: Amino acid composition of atomized HO8 sample

\begin{tabular}{|c|c|c|c|c|}
\hline \multicolumn{5}{|c|}{ SAMPLE HO8 atomized hydrolysate } \\
\hline No. & Retention time & Compound & $\begin{array}{l}\text { Majority } \\
\text { fragment }\end{array}$ & $\%$ \\
\hline 1 & 8.67 & Alanine & 116 & 14.96 \\
\hline 2 & 8.98 & Glycine & 102 & 16.92 \\
\hline 3 & 10.25 & Valine & 144 & 1.90 \\
\hline 4 & 10.87 & Glycerol & 147 & 0.03 \\
\hline 5 & 10.96 & Leucine & 158 & 4.18 \\
\hline 6 & 11.22 & Isoleucine & 158 & 0.87 \\
\hline 7 & 11.41 & Proline & 142 & 29.67 \\
\hline 8 & 11.9 & Serine & 204 & 6.98 \\
\hline 9 & 12.15 & Threonine & 218 & 1.95 \\
\hline 10 & 13.4 & Acid Aspartic & 232 & 8.98 \\
\hline 11 & 13.44 & Hydroxyproline & 230 & 11.02 \\
\hline 12 & 14.1 & Tartaric acid & 147 & 0.96 \\
\hline 13 & 14.29 & Phenylalanine & 218 & 0.66 \\
\hline 14 & 15.74 & Lysine & 174 & 0.91 \\
\hline
\end{tabular}

\section{CONCLUSIONS}

Validation of the method included assessment of independent acid hydrolysis procedures, amino acid derivatization and GC/ MS analysis.

To fully evaluate the performance of these procedures, a standard amino acid mixture allowed the GC/MS method to be verified, including derivatization and effects of acid hydrolysis on amino acids.

The validated analytical method for determining the amino acid content of collagen biomaterials for medical purposes fulfills all the conditions necessary for use and application for the intended purposes.

It was shown that this method can be used both for collagen hydrolysates and gels as well as for spongy collagen matrices because it is repeatable and reproducible.

Acknowledgment

This study was funded by $\mathrm{MCl}$ in the frame of Nucleu program 2016-2017, project code PN 163404 04, contract 26N/2016.

\section{REFERENCES}

1. Albu, M.G., Titorencu, I., Chelaru, C., The stability of some collagen hydrohels, Leather and Footwear Journal, 2011, 11, 1, 11-20.

2. Albu, M.G., Titorencu, I., Biocompatibility study of collagen nerve conductors, Leather and Footwear Journal, 2011, 11, 4, 329-340.

3. Albu, M.G., Ghica, M.V., Tang, K., Liu, J., Coara,
Gh., Rheological behavior of some collagen extracts, Leather and Footwear Journal, 2012, 12, 3, 193-200.

4. Vranceanu, M.D., Saban, R., Albu, M.G., Antoniac, I., Preparation and characterization of collagen: amorphous calcium phosphate composites, Leather and Footwear Journal, 2012, 12, 3, 215-222.

5. Albu, M.G., Leca, M., Trandafir, V., Rheological Behavior of Some Collagen Creams, Leather and Footwear Journal, 2012, 12, 4, 257-270.

6. Albu, M.G., Trandafir, V., Leca, M., Carsote, C., Characterization of collagen-gentamicin systems used in controlled release of drugs, Leather and Footwear Journal, 2007, 4, 3-9.

7. Albu, M.G., Ficai, A., Lungu, A., Preparation and characterization of collagen matrices obtained at different freezing temperatures, Leather and Footwear Journal, 2010, 10, 3, 39-50.

8. Shoulders, M.D., Raines, R.T., Collagen structure and stability, Annu Rev Biochem, 2009, 78, 929-958, https://doi.org/10.1146/ annurev.biochem.77.032207.120833.

9. Bhattacharjee, A., Bansal, M., Collagen Structure: The Madras Triple Helix and the Current Scenario, Life, 2005, 57, 3, 161-172, https://doi. org/10.1080/15216540500090710.

10. Macovescu, G., Chelaru, C., Albu Kaya, M.G., Albu, L., Determination of Hydroxyproline in Collagen Biomaterials for Medical Use and 
Validation of Method, Leather and Footwear Journal, 2016, 16, 2, 147-162, https://doi. org/10.24264/Ifj.16.2.5.

11. Zumwalt, R.D., Kuo, K.C.T., Gehrke, C.W., Eds., Amino Acid Analysis by Gas Chromatography, vols. I-III, CRC Press, Boca Raton, Florida, 1987.

12. Molnar-Perl, I., Katona, Z.F., GC-MS of Amino Acids as their Trimethylsilyl/t-butyldimethylsilyl Derivatives: in Model Solutions III, Chromatographia, 2000, 51, 1, S228-S236.

13. Kaspar, H., Dettmer, K., Gronwald, W., Oefner, P.J., Automated GC-MS Analysis of Free Amino Acids in Biological Fluids, J Chromatogr B Analyt Technol Biomed Life Sci, 2008, 870, 222-232, https://doi. org/10.1016/j.jchromb.2008.06.018.

14. Miller, J., Chromatography: Concepts and Contrasts, John Wiley \& Sons Inc., Hoboken, NJ, 2005.

15. Gehrke, C.W., Nakamato, H., Zumwait, R.W., Gas-Liquid Chromatography of Protein Amino Acids Trimethylsilyl Derivatives, J Chromatogr, 1969, 45, 24-51, https://doi. org/10.1016/S0021-9673(01)86179-3.

16. Kühnel, E., Laffan, D.D., Lloyd-Jones, G.C., Martínez,C.T.,Shepperson, I.R.etal.,Mechanism of Methyl Esterification of Carboxylic Acids by Trimethylsilyldiazomethane, Angew Chem Int Ed Engl, 2007, 46, 7075-7078, https://doi. org/10.1002/anie. 200702131.

17. Gehrke, C.W., Leimer, K., Trimethylsilylation of amino acids. Effect of solvents on derivatization using bis(trimethylsilyl)trifluoroacetamide, J Chromatogr, 1970, 53, 201-208, https://doi. org/10.1016/S0021-9673(01)98459-6.

18. Berezin, V.G., Capillary Gas-Solid Chromatography, Usp Khim, 1996, 65, 991-1012.

19. Robards, K., Haddad, P.R., Jackson, P.E., Principles and Practice of Modern Chromatographic Methods, Academic Press, San Diego, CA, 1994.

20. Shen, X., Deng, C., Wang, B., Dong, L., Quantification of Trimethylsilyl Derivatives of Amino Acid Disease Biomarkers in Neonatal Blood Samples by Gas Chromatography-Mass Spectrometry, Anal Bioanal Chem, 2006, 384, 931-938, https://doi.org/10.1007/s00216005-0241-0.

21. An, Y., Schwartz, Z., Jackson, G.P, $\delta 13 C$ Analysis of Amino Acids in Human Hair Using Trimethylsilyl Derivatives and Gas
Chromatography/Combustion/Isotope Ratio Mass Spectrometry, Rapid Commun Mass Spectrom, 2013, 27, 1481-1489.

22. Bruckner, H., Lupke, M., Use of chromogenic and fluorescent oxy-carbonyl chlorides as reagents for amino acid analysis by highperformance liquid chromatography, J Chromatogr, 1995, A697,1-2, 295-307, https:// doi.org/10.1016/0021-9673(94)00938-6.

23. Bank, R.A., Jansen, E.J., Beekman, B., te Koppele, J.M., Amino acid analysis by reverse-phase highperformance liquid chromatography: improved derivatization and detection conditions with 9-fluorenylmethyl chloroformate, Anal Biochem, 1996, 240, 2, 167-76, https://doi. org/10.1006/abio.1996.0346.

24. Bjørklund, J., Einarsson, S., Engstrøm, A., Grzegorczykd, A., Beckere, H.D., Josefssona, B., Automated amino acid determination by high-performance liquid chromatography with 2-(9-anthryl)ethyl chloroformate as precolumn reagent, J Chromatogr, 1998, A 798, 1-2, 1-8, https://doi.org/10.1016/s00219673(97)00987-4.

25. Chaimbault, P., Petritis, K., Elfakir, C., Dreux, M., Ion-pair chromatography on a porous graphitic carbon stationary phase for the analysis of twenty underivatized protein amino acids, J Chromatogr, 2000, A 870, 245-254, https://doi. org/10.1016/S0021-9673(99)00863-8.

26. Haynes, P.A., Sheumack, D., Greig, L.G., Kibby, J., Redmond, J.W., Applications of automated amino acid analysis using 9-fluorenylmethyl chloroformate, J Chromatogr, 1991, 588, 1-2, 107-114, https://doi.org/10.1016/00219673 (91)85012-5.

27. Šimek, P., Heydová, A., Jegorov, A., High resolution capillary gas chromatography and gas chromatography - mass spectrometry of protein and non-protein amino acids, amino alcohols, and hydroxycarboxylic acids as their tert-butyldimethylsilyl derivatives, J High Resolut Chromatogr, 1994,17, 145-152,https:// doi.org/10.1002/jhrc.1240170305.

(C) 2017 by the author(s). Published by INCDTPICPI, Bucharest, RO. This is an open access article distributed under the terms and conditions of the Creative Commons Attribution license (http:// creativecommons.org/licenses/by/4.0/). 